\title{
Association between TGF $\beta 1$ polymorphisms and chronic hepatitis B infection in an Iranian population
}

\author{
Ebrahim Eskandari ${ }^{[1],[2]}$, Malihe Metanat ${ }^{[3]}$, Elham Pahlevani ${ }^{[3]}$ \\ and Tooba Nakhzari-Khodakheir ${ }^{[4]}$
}

[1]. Genetic of Non-Communicable Disease Research Center, Zahedan University of Medical Sciences, Zahedan, Iran. [2]. Department of Clinical Biochemistry, School of Medicine, Zahedan University of Medical Sciences, Zahedan, Iran. [3]. Infectious Diseases \& Tropical Medicine Research Center, Zahedan University of Medical Sciences, Zahedan, Iran. [4]. Biology Department, School of Science, University of Sistan and Baluchestan, Zahedan, Iran.

\begin{abstract}
Introduction: Transforming growth factor-beta 1 (TGF $\beta 1$ ) is a potent suppressive cytokine that contributes to chronic hepatitis B (CHB) infection. Disparities in TGF $\beta 1$ production among individuals have been attributed to TGF $\beta 1$ genetic polymorphisms. We examined whether three putative polymorphisms in TGF31[-509 C/T (rs1800469), +869 C/T (rs1800470), and +11929 C/T (rs1800472)] are associated with CHB infection in a South-Eastern Iranian population. Methods: In total, 341 subjects were recruited, including 178 patients with CHB and 163 healthy individuals as controls. Genotyping of the three TGF $\beta 1$ SNPs was performed by tetra amplification refractory mutation system-PCR. Results: TheTGF $\beta 1+869$ TT vs.CC genotype in codominant $(\mathrm{OR}=0.445, \mathrm{p}=0.012)$ and $\mathrm{TT}$ vs. $\mathrm{TC}+\mathrm{CC}$ in the recessive $(\mathrm{OR}=0.439, \mathrm{p}=0.003)$ model as well as the variant allele $\mathrm{T}$ vs. $\mathrm{C}(\mathrm{OR}=0.714, \mathrm{p}=0.038)$ were associated with lower $\mathrm{CHB}$ infection risk. However, the $+11929 \mathrm{C} / \mathrm{T}$ polymorphism was associated with increased $\mathrm{CHB}$ risk, and the $\mathrm{CT}$ vs. $\mathrm{CC}$ genotype $(\mathrm{OR}=2.77, \mathrm{P}=0.001)$ and $\mathrm{T}$ variant allele $(\mathrm{OR}=2.53, \mathrm{P}=0.002)$ were risk factors for CHB. Furthermore, TTT $(+869 /-509 /+11929)$ and CCC haplotypes were risk and protective factors for $\mathrm{CHB}$, respectively. We found no significant association between viral DNA load and TGF $\beta 1$ genotype or hepatic enzyme levels $(\mathrm{p}>0.05)$. Conclusions: Results indicated that the TGF $\beta 1+869 \mathrm{TT}$ genotype and T allele were protective factors, whereas the +11929 CT genotype and T allele were risk factors for CHB infection.
\end{abstract}

Keywords: Chronic hepatitis B infection. Gene polymorphism. TGF $\beta 1$.

\section{INTRODUCTION}

Hepatitis B virus (HBV) is the most frequent cause of acute and chronic liver disease worldwide. HBV infects more than 350 million people globally, especially in developing countries of Asia and Africa. Over $90 \%$ of adult onset infections are resolved within 6 months, with or without clinical symptoms. However, $5-10 \%$ of cases develop into persistent infections, which are defined as chronic hepatitis B (CHB);these can present as more severe forms such as liver cirrhosis and hepatocellular carcinoma. The risk of HBV persistence is related to two main factors: host immunological ${ }^{1}$, and genetic ${ }^{2}$.

Many studies have suggested that cytokines are critical for the development of a proper immune response against HBV, to eradicate the viral infection, and control hepatitis B-associated complications including cirrhosis of the liver and hepatocellular carcinoma (HCC). Transforming growth factor-beta 1 (TGF $\beta 1)$ is

Corresponding author: Mrs. Elham Pahlevani.

e-mail: elham_pahlavani@yahoo.com

Received 30 June 2016

Accepted 6 March 2017 a potent suppressive cytokine involved in the cellular immune response, and is also important for various physiological processes in the liver, as it promotes apoptosis and inhibits hepatocyte proliferation in addition to its crucial role in hepatic fibrogenesis ${ }^{3}$. This molecule is produced by a number of cell types, including monocytes, macrophages, endothelial cells, and vascular smooth muscle cells and is also released from a variety of liver cells, including hepatocytes and hepatic stellate cells (HSC) in addition to platelets and infiltrating mononuclear cells $\mathrm{s}^{4}$. Compared to healthy subjects, $\mathrm{CHB}$ patients have been shown to express higher levels of serum TGF $\beta 1$, resulting in dysregulation of the host immune response $\mathrm{e}^{5,6}$. As a multifunctional cytokine, TGF $\beta 1$ hinders the propagation, differentiation, and activation of immune cells, and plays key roles in the regulation of viral replication and host responses to pathogens ${ }^{7}$.

Growing evidence suggests that genetic variations in immune-related genes such as TGF $\beta 1$ are associated with CHB risk or progression ${ }^{4,8,9}$. Host genetic background, particularly single nucleotide polymorphisms (SNPs), have been shown to be a crucial factor for associated clinical heterogeneity ${ }^{10}$. TGF $\beta$ is encoded by three different genes, namely TGF $\beta 1$, TGF $\beta 2$, and TGF $\beta 3$. Human TGF $\beta 1$ is located on chromosome 19q13.1 and 
variation among individuals in terms of TGF $\beta 1$ production is considered to be genetically controlled ${ }^{8}$.

Three putative polymorphisms of TGF $\beta 1$ include a $\mathrm{C} / \mathrm{T}$ transition at the -509 position of the promoter region, $\mathrm{a}+869$ $\mathrm{T} / \mathrm{C}$ transition in codon 10 of exon 1 , and the $+11929 \mathrm{C} / \mathrm{T}$ polymorphism in exon 5 . Recent studies have shown that the $\mathrm{T}$ allele of the $-509 \mathrm{C} / \mathrm{T}$ ( $\mathrm{rs} 1800469)$ variation is associated with high production of TGF $\beta 1$ and a lower risk of $\mathrm{CHB}^{11,12}$. Additionally, the exon $1 \mathrm{SNP}+869 \mathrm{C} / \mathrm{T}$ (rs1800470)located at position 29 involves an amino acid change of proline to leucine at position 10 of the signal peptide ofTGF $\beta 1^{13}$. Another SNP, $+11929 \mathrm{C} / \mathrm{T}$ (rs1800472) in exon 5, results in the amino acid replacement of Thr263Ile, and is related to the activation of TGF $\beta 1^{14}$.

TGF $\beta 1$ polymorphisms have been evaluated in a number of infectious diseases, including Mycobacterium tuberculosis (TB) infection ${ }^{15}$, brucellosis ${ }^{7,16}$, hepatitis $\mathrm{C}$ virus (HCV) infection ${ }^{6,17}$, and $\mathrm{CHB}^{5,18,19}$; however, results have been inconsistent. Considering solid evidence implicating TGF $\beta 1$ polymorphisms in infectious diseases, the current study was designed to investigate the potential relationships between three genetic polymorphisms inTGF $\beta 1$, including $-509 \mathrm{C} / \mathrm{T},+869 \mathrm{C} / \mathrm{T}$, and $+11929 \mathrm{C} / \mathrm{T}$, and the risk of CHB in a South-East Iranian population. To the best of our knowledge, this is the first study examining TGF $\beta 1$ variations and CHB in this population.

\section{METHODS}

\section{Study population}

The current case-control study included $178 \mathrm{CHB}$ patients (114 men and 64 women; age range 15-68 years and mean \pm SD $=34.02 \pm 10.1)$ and 163 healthy individuals as the control group (108 men and 55 women; age range 17-58 years and mean \pm SD $=33.84 \pm 23.2$ ). Patients with CHB infection were recruited from blood transfusion organization outpatient clinics in Zahedan, during 2013-2015, and their ethnicity was Fars or Balouch. The research was executed at the Infectious Diseases and Tropical Medicine Research Center, Zahedan University of Medical Sciences, and the study was approved by the ethics committee of Zahedan University of Medical Sciences, Zahedan; all patients gave informed consent before taking part in the study.

\section{Viral assessment and HBV DNA quantification}

Chronic hepatitis B was determined as positivity for HBsAg for a minimum of 6 months. All patients were positive for hepatitis B surface antigen (HBsAg) and HBV-DNA and negative for $\mathrm{HCV}$ antibodies. The main exclusion criteria included human immunodeficiency virus or $\mathrm{HCV}$ co-infection, or any evidence of clinically relevant liver disease such as apparent auto-immune hepatitis-primary biliary cirrhosis, HCC, former history of alcohol abuse, or previous liver transplantation. HBsAg and $\mathrm{HCV}$ antibodies were tested using a commercial kit (Enzygnost, Germany). HBV-DNA in HBVpositive patients was extracted and tested by polymerase chain reaction (PCR) (Cinagen, Iran) and quantified by quantitative PCR (qPCR) (ABI 7800, Applied Biosystems, Foster City, CA). Patients were stratified into two groups according to their viral DNA loads ${ }^{20}$. Group 1 included patients with low serum HBV DNA levels $(<2,000 \mathrm{IU} / \mathrm{mL} ; \mathrm{n}=63)$ and group 2 included patients with high titers of HBV DNA $(\geq 2,000 \mathrm{IU} / \mathrm{mL} ; \mathrm{n}=34)$.

The control group included healthy blood donors from the same geographic area and with the same ethnicity, who were anti-HBs- and anti-HBc-positive (resolved HBV) with no history of previous liver disease. There was no difference between groups regarding gender or ethnicity.

\section{DNA isolation and genotyping of TGF 31 SNPs $(-509 \mathrm{C} / \mathrm{T},+869 \mathrm{C} / \mathrm{T}$, and $+11929 \mathrm{C} / \mathrm{T})$}

Blood samples were collected by withdrawing $5 \mathrm{~mL}$ of venous blood into sterile EDTA-containing tubes. DNA was extracted by the salting-out method, as described previously ${ }^{21,22}$. The isolated DNA was examined by electrophoresis using a $1 \%$ agarose gel, quantified spectrophotometrically, and stored at $-20{ }^{\circ} \mathrm{C}$ until further use.

The threeTGF $\beta 1$ polymorphisms, $-509 \mathrm{C} / \mathrm{T},+869 \mathrm{C} / \mathrm{T}$, and $+11929 \mathrm{C} / \mathrm{T}$, were genotyped by the tetra-primer amplification refractory mutation system-polymerase chain reaction (T-ARMS-PCR) method, as described previously ${ }^{23}$. T-ARMSPCR utilizes four primers including two external primers (control band) and two inner primers (allele specific primers). This method simultaneously amplifies both alleles in one single PCR tube. The cycling conditions for T-ARMS-PCR were an initial denaturation at $95^{\circ} \mathrm{C}$ for $5 \mathrm{~min}$ followed by 30 cycles of $30 \mathrm{~s}$ at $95^{\circ} \mathrm{C}$, annealing for $30 \mathrm{~s}$ at $60^{\circ} \mathrm{C}$ for $-509 \mathrm{C} / \mathrm{T}, 30 \mathrm{~s}$ at $65^{\circ} \mathrm{C}$ for $+869 \mathrm{C} / \mathrm{T}$, and $30 \mathrm{~s}$ at $63^{\circ} \mathrm{C}$ for $+11929 \mathrm{C} / \mathrm{T}$, and a final cycle of $72^{\circ} \mathrm{C}$ for $10 \mathrm{~min}$.

PCR products were separated by standard electrophoresis on a $2 \%$ agarose gel containing ethidium bromide. The primer sequences and products sizes are shown in Table $\mathbf{1 .}$

\section{Statistical analysis}

All statistical analyses were performed using SPSS software for Windows, version 18.0 (SPSS Inc, Chicago IL, USA). The association between genotypes and CHB was calculated by estimating the odds ratio (OR) and $95 \%$ confidence intervals $(95 \% \mathrm{CI})$ based on logistic regression analyses. P-values below 0.05 were considered statistically significant. The HardyWeinberg equilibrium (HWE), differences in the distribution of the haplotype, and diplotype distributions between the two groups were assessed by the $\chi 2$ test. Linkage disequilibrium and frequencies of haplotypes and diplotypes in the controls and patients were calculated using SNPStats software ${ }^{24}$.

\section{RESULTS}

\section{Genotype frequencies of TGF $\beta 1-509 \mathrm{C} / \mathrm{T},+869 \mathrm{C} / \mathrm{T}$, and $+11929 \mathrm{C} / \mathrm{T}$ polymorphisms}

ThreeTGF $\beta 1$ polymorphisms were successfully genotyped in CHB patients and control subjects. No SNPs had genotype frequencies that deviated significantly from the HWE in the studied control groups ( $>0.05)$, except for the $-509 \mathrm{C} / \mathrm{T}$ variation $(p=0.01)$.The genotype and allele frequencies of thethreeTGF $\beta 1$ gene polymorphisms in the studied groups are shown in Table 2. 


\section{TABLE 1}

Primers used for genotyping of TGF $\beta 1$ gene polymorphisms and amplicon sizes.

\begin{tabular}{|c|c|c|c|}
\hline SNPs & Name $^{1}$ & Primer sequence & Amplicons size (bp) \\
\hline \multicolumn{4}{|l|}{ TGF $\beta 1$ SNPs } \\
\hline \multirow[t]{3}{*}{$-509 \mathrm{C} / \mathrm{T}$} & FO & AGTAAATGTATGGGGTCGCAGGGTGTTG & 295 \\
\hline & FI (T allele) & GGTGTCTGCCTCCTGACCCTTCCATACT & 207 \\
\hline & RI (C allele) & GAGGAGGGGGCAACAGGACACCTTAG & 141 \\
\hline & $\mathrm{RO}$ & TTCCGCTTCACCAGCTCCATGTCGATAG & \\
\hline & FI (T allele) & CTCCGGGCTGCGGCTGCTTCT & 123 \\
\hline & RI (C allele) & AGTAGCCACAGCAGCGGTAGCAGCATCG & 180 \\
\hline$+11,929 \mathrm{C} / \mathrm{T}$ & FO & AGAGTGTGTGTGTATGTCCCCTATCCCC & 313 \\
\hline
\end{tabular}

TGFß1: transforming growth factor-beta 1; SNP: single nucleotide polymorphisms; bp: base-pair; FO: forward outer; RO: reverse outer; FI: forward inner; RI: reverse inner; Nucleotide specificity is shown in parentheses.

TABLE 2

Genotype and allele frequencies of TGF $\beta 1$ SNPs between chronic hepatitis B virus (HBV)-infected patients and controls.



TGFß1: transforming growth factor-beta 1; SNP: single nucleotide polymorphisms; HBV: hepatitis B virus; OR: odds ratio; CI: confidence interval; .*Adjusted for age and sex. OR. 
TheTGF $\beta 1+869 \mathrm{C} / \mathrm{T}$ polymorphism was associated with a decreased rate of CHB infection. The mutant homozygote genotype (TT vs. CC) was present at a significantly lower frequently in CHB patients than in controls (12\% vs. $23 \%)$, and this was associated with reduced risk of CHB infection $(\mathrm{OR}=0.445,95 \% \mathrm{CI}=0.237-0.838, \mathrm{p}=0.012)$. Likewise, at the allelic level, for TGF $\beta 1+869$, the variant allele $\mathrm{T}$ was less prevalent in CHB patients than in controls (42 vs. 49) and was a protective factor against $\mathrm{CHB}$ development $(\mathrm{OR}=0.714$, $95 \% \mathrm{CI}=0.559-0.982, \mathrm{p}=0.038$ ).

The TGF $\beta 1+11929 \mathrm{C} / \mathrm{T}$ polymorphism was associated with increased susceptibility to CHB infection. The heterozygote genotype (CT vs. CC) was present significantly more frequently in CHB patients than in controls ( $23 \%$ vs. $10 \%$ ), and it was a risk factor for $\mathrm{CHB}$ infection $(\mathrm{OR}=2.765,95 \% \mathrm{CI}=1.471-5.164$, $\mathrm{p}=0.001$ ). In addition, at the allelic level, for TGF $\beta 1+11929$, the variant allele $T$ was more prevalent in CHB patients than in controls (11 vs. 5) and was found to be a risk factor forCHB development $(\mathrm{OR}=2,527,95 \% \mathrm{CI}=1,382-4,613, \mathrm{p}=0.002)$ in our population.

With respect to other TGF $\beta 1 \mathrm{SNPs}$, for $-509 \mathrm{C} / \mathrm{T}$, the genotypes and allele distributions did not significantly differ between patients and neither was associated with CHB risk $(\mathrm{p}>0.05)$.

\section{Linkage disequilibrium and haplotype association analysis of TGFß1polymorphisms}

Linkage disequilibrium (LD) was computed by calculating Lewontin's Delta' coefficient and the correlation coefficient, $\mathrm{r}^{2,25}$. Pairwise LD between the TGF $\beta 1$ SNPs $-509 \mathrm{C} / \mathrm{T},+869 \mathrm{C} / \mathrm{T}$, and $+11929 \mathrm{C} / \mathrm{T}$ was calculated for cases and controls. Analysis of the TGF $\beta 1$ SNPs demonstrated a moderate LD for the TGF $\beta 1$
SNP pair, $-509 \mathrm{C} / \mathrm{T}$ and $+869 \mathrm{C} / \mathrm{T}\left(\mathrm{D}^{\prime}=0.689 \mathrm{r}^{2}=0.315\right)$, but no LD was observed between other TGF $\beta 1$ SNP pairs, namely $-509 \mathrm{C} / \mathrm{T}$ and $+11929\left(\mathrm{D}^{\prime}=0.076, \mathrm{r}^{2}=0.001\right)$ or $+869 \mathrm{C} / \mathrm{T}$ and $+11929 \mathrm{C} / \mathrm{T}\left(\mathrm{D}^{\prime}=0.021, \mathrm{r}^{2}=0.001\right)$. Table 3 shows haplotype association analyses for TGF $\beta 1$ polymorphisms in CHB patients and controls. The TTT and CCC haplotypes (+869/-509/+11929; $\mathrm{p}=0.003$ ) were distributed differently in CHB patients compared to that in controls. The TTT haplotype was associated with an increased risk of $\mathrm{CHB}(\mathrm{OR}=4.253,95 \% \mathrm{CI}=1.487-12.16$, $\mathrm{p}=0.003)$, whereas the $\mathrm{CCC}$ haplotype was associated with a reduced risk of $\mathrm{CHB}(\mathrm{OR}=0.655,95 \% \mathrm{CI}=0.448-0.957$, $\mathrm{p}=0.028)$. Owing to the small number of subjects, the haplotype findings should be interpreted with caution. Meanwhile, we performed pairwise diplotype analysis among the three TGF $\beta 1$ SNPs but the results were not statistically significant (data not shown).

Table 4 demonstrates the stratification of hepatitis B patients, based on their viral DNA load, as well as the relationship between patient sex, age, and mean level of liver enzymes and TGF $\beta 1$ genotypes. We observed that TGF $\beta 1$ genotypes were distributed equally in two groups with high and low HBV DNA levels, and the difference was not statistically significant $(\mathrm{P}>0.05)$. However, HBV DNA levels were associated with mean patient age $(\mathrm{P}=0.001)$, but not with gender or liver enzyme levels $(\mathrm{p}>0.05)$.

Furthermore, we compared the relationships between the levels of hepatic enzymes (ALT, AST, and ALP) and different TGF $\beta 1$ genotypes $(\mathrm{p}>0.05)$ among the CHB patients. ANOVA analysis (Tukey test) of the genotypes indicated that there was no significant association between $T G F \beta$ lgenotypes and the quantity of hepatic enzymes $(\mathrm{P}>0.05)$ (data not shown).

TABLE 3

Haplotype association analyses for TGF $\beta 1-509 \mathrm{C} / \mathrm{T},+869 \mathrm{C} / \mathrm{T}$, and $+11929 \mathrm{C} / \mathrm{T}$ polymorphisms between chronic hepatitis B patients and controls

\begin{tabular}{|c|c|c|c|c|}
\hline Haplotype $^{*}$ & Case/Freq $(\%)$ & Control/Freq (\%) & OR $(95 \% \mathrm{CI})$ & P-value \\
\hline \multicolumn{5}{|c|}{ TGF $\beta 1$ SNPs+869/-509/+11929 } \\
\hline $\mathrm{CCC}$ & $68(0.2)$ & $81(0.3)$ & $0.655(0.448-0.957)$ & 0.028 \\
\hline CTC & $42(0.15)$ & $40(0.16)$ & $0.908(0.567-1.455)$ & 0.689 \\
\hline CTT & $4(0.01)$ & $4(0.14)$ & $0.844(0.187-3.813)$ & 0.825 \\
\hline TCC & $19(0.06)$ & $9(0.03)$ & $2.024(0.890-4.605)$ & 0.087 \\
\hline
\end{tabular}

TGFß1: transforming growth factor-beta 1; SNP: single nucleotide polymorphisms; OR: odds ratio; CI: confidence interval. ${ }^{*}$ Haplotype analysis for frequencies below 0.01 was not performed. Bold numbers depict $\mathrm{p}<0.05$. 
TABLE 4

Stratification of hepatitis B patients based on viral DNA load, and relationships between patient sex, age, and mean level of liver enzymes and TGF $\beta 1$ genotypes.

\begin{tabular}{|c|c|c|c|}
\hline Parameter & $\begin{array}{l}\text { Patients with low HBV DNA levels } \\
\qquad(<2,000 \mathrm{MU} / \mathrm{mL})\end{array}$ & $\begin{array}{l}\text { Patients with high HBV DNA levels } \\
\qquad(>2,000 \mathrm{MU} / \mathrm{mL})\end{array}$ & P-value \\
\hline Sex (male/female) & $20 / 15$ & $46 / 18$ & 0.137 \\
\hline Age (years) & 31 & 41.5 & 0.001 \\
\hline ALT (IU/L) & 29.7 & 27.4 & 0.441 \\
\hline $\operatorname{ALP}(\mathrm{IU} / \mathrm{L})$ & 193.3 & 159.1 & 0.326 \\
\hline \multicolumn{4}{|l|}{$\mathrm{TGF} \beta 1+869 \mathrm{C} / \mathrm{T}$} \\
\hline $\mathrm{CC}(\%)$ & $20(32.0)$ & $30(31.0)$ & Ref. \\
\hline $\mathrm{CT}(\%)$ & $36(58.0)$ & $55(57.0)$ & 0.995 \\
\hline $\mathrm{CC}(\%)$ & $28(45.0)$ & $14(40.0)$ & Ref. \\
\hline $\mathrm{CT}(\%)$ & $28(45.0)$ & $14(40.0)$ & 0.998 \\
\hline TT (\%) & $6(10.0)$ & $7(20.0)$ & 0.315 \\
\hline \multicolumn{4}{|l|}{ TGF $\beta 1+11929 \mathrm{C} / \mathrm{T}$} \\
\hline $\mathrm{CC}(\%)$ & $44(73.0)$ & $26(74.0)$ & Ref. \\
\hline $\mathrm{CT}(\%)$ & $16(27.0)$ & $9(26.0)$ & 0.994 \\
\hline
\end{tabular}

DNA: deoxyribonucleic acid; TGFß1: transforming growth factor-beta 1; HBV: hepatitis B virus; ALT: alanine aminotransferase; AST: aspartate transaminase; ALP: alkaline phosphatase; MU/mL: mili units/millilitre; IU:/L: international Units/liter.

\section{DISCUSSION}

Growing evidence has suggested defective cellular and humoral immune functions in patients with CHB infection; this could be directly related to the chronicity of the disease ${ }^{26}$. In general, patients with CHB infection have a weak, relatively unfocused intra-hepatic and systemic immune response to $\mathrm{HBV}$ antigens ${ }^{27}$. Animal studies have shown an increase in the levels of TGF $\beta 1$ and TNF- $\alpha$ during hepatic fibrogenesis, and this contributes to fibrin matrix formation and liver fibrosis ${ }^{28,29}$.

Our results showed that TGF $\beta 1+869 \mathrm{C} / \mathrm{T}$ and $+11929 \mathrm{C} / \mathrm{T}$ polymorphisms were associated with lower and higher risk of CHB infection, respectively. The TGF $\beta 1+869$ homozygote genotype (TT) might confer protection against CHB in the tested population. The carriers of the TT genotype had a comparatively (0.4-fold) lower risk of CHB than subjects with $\mathrm{CC}$ or $\mathrm{CC}+\mathrm{CT}$ genotypes. Likewise, the TGF $\beta 1+869 \mathrm{~T}$ variant was associated with a reduced risk of $\mathrm{CHB}(\mathrm{OR}=0.7)$. Concerning TGF $\beta 1+11929 \mathrm{C} / \mathrm{T}$, we found that the CT genotype as well as the $\mathrm{T}$ allele were related to an increased risk of CHB. In addition, subjects harboring either the CT genotype or the $\mathrm{T}$ allele had a relatively (2.8- or 2.5 -fold, respectively) increased risk of CHB in our population. Furthermore, the TTT $(+869 /-$ $509 /+11929)$ haplotype carriers had a 4.2-fold higher risk of
CHB. However, the CCC $(+869 /-509 /+11929)$ haplotype was shown to potentially confer protection against $\mathrm{CHB}$ in our population $(\mathrm{OR}=0.6)$.

Our data regarding the TGF $\beta 1+869 \mathrm{C} / \mathrm{T}$ polymorphism were similar to those of several studies on inflammatory and infectious diseases such as chronic periodontitis ${ }^{23}$, Crohn's disease $^{30}$, childhood asthma ${ }^{31}$, multiple sclerosis (MS) ${ }^{32}$, and $\mathrm{TB}^{33}$. Schrijver et al. reported that TGFB1 $\mathrm{T}+869 \mathrm{C}$ variation is associated with MS susceptibility, especially in males, and with a more destructive disease course ${ }^{32}$. However, the study by Ribeiro et $\mathrm{a}^{34}$ on CHB and the report of Mak et a ${ }^{35}$ on TB showed no relation between TGF $\beta 1$ gene polymorphisms and disease risk. Our findings regarding TGF $\beta 1-509 \mathrm{C} / \mathrm{T}$ support the results of Hosseini Razavi et al. who found no association between the TGF $\beta 1-509 \mathrm{C} / \mathrm{T}$ polymorphism and $\mathrm{CHB}$ in an Iranian population. Compared to their study, our study is a populationbased study performed on individuals from a South-Eastern Iranian population; however, their study was a hospital-based study performed using samples obtained from the Taleghani Hospital in Tehran, the capital city of Iran, and these samples were from individuals of a different ethnicity compared to that of our subjects 5 . Although both studies examined the effect of the TGF $31-509 \mathrm{C} / \mathrm{T}$ polymorphism on CHB, we also examined two 
other gene polymorphisms ( $+869 \mathrm{C} / \mathrm{T}$ and $+11929 \mathrm{C} / \mathrm{T}$ ), where were not included in the study of Hosseini Razavi et $\mathrm{al}^{5}$.

The 11929C/T SNP (Thr263Ile; rs1800472), located in exon 5 , is close to the latency-associated peptide cleavage site, required to activate the protein. Hence, this SNP might affect the activation process of TGF $\beta 1^{13}$. In support of this report, we previously found that the risk of $\mathrm{CHB}$ is higher among those with the high producer allele $\mathrm{T}$ (Ile) than in those with the $\mathrm{C}(\mathrm{Thr})$ allele $^{12}$. The +11929 C/T SNP has been the basis of a number of studies; however, it was not shown to be associated with the risk of chronic periodontitis ${ }^{23}$ or childhood asthma ${ }^{31}$.

TGF $\beta 1$ is located on chromosome $19 \mathrm{q} 13$ and consists of 23,020 base pairs, including six introns and seven exons. TGF $\beta 1$ exhibits bi-allelic polymorphisms at position $-509 \mathrm{C} / \mathrm{T}$ in the promoter region and two bi-allelic polymorphisms in exon $1(+869 \mathrm{C} / \mathrm{T})$ and exon $5(+11929 \mathrm{C} / \mathrm{T})^{21}$. The TGF $\beta 1+869$ $\mathrm{C} / \mathrm{T}$ substitution (rs1800470) results in a proline (CCG) to leucine (CTG) change at codon 10 (Pro10Leu) of the protein. This genetic alteration occurs in the signal peptide, which is involved in export of the pre-pro-protein across the endoplasmic reticulum membrane. The +869 Leu allele $(\mathrm{T})$ has been shown to elevate the secretion of this cytokine in breast cancer ${ }^{36}$, lung fibrosis $^{37}$, and schizophrenia ${ }^{38}$.In contrast, some studies have reported that the Pro allele $(\mathrm{C})$ of $+869 \mathrm{C} / \mathrm{T}$ is related to higher serum levels, compared to those associated with the Lue (T) allele, in HCC patients ${ }^{12}$. A transfection study using HeLa cells also indicated that the allele (C) encoding Pro 10 is associated with increased rates of TGF $\beta 1$ secretion $^{39}$. In agreement with the latter studies, our findings showed that the risk of CHB was lower among those with the lower producer genotype TT (Leu/Leu), when compared to that in individuals with the CC genotype $^{12}$. Dual roles of TGF- $\beta$ in immune system regulation can explain the conflicting results; different studies have shown that TGF- $\beta$ can have either positive or negative effects on hepatitis B infection.

TGF $\beta$ has dual roles in the regulation of the immune system. It induces the differentiation of Th17 cells, the main source of IL-17A, which is essential for both the initiation and maintenance of appropriate immune responses against microbes; in addition, it is involved in the development of cirrhosis of the liver and $\mathrm{HCC}^{7,40,41,42}$. In contrast, it can increase the number and activation of $\mathrm{T}$ regulatory lymphocytes and the recruitment of these cells to the infected liver; this leads to prolonged hepatitis $\mathrm{B}$ infection. Prolonged infection with the chronic, asymptomatic, and occult forms of hepatitis B contributes to $\mathrm{HCC}$ and cirrhosis of the liver ${ }^{43}$. The mechanisms responsible for the prolonged hepatitis B infection, HCC, and cirrhosis of the liver are not entirely understood.

Our study was a population-based study of SouthEastern Iranians. Similarly, Hosseini Razavi et $\mathrm{al}^{5}$ examined the association between TGF $\beta 1+915 \mathrm{G} / \mathrm{C}$ and $-509 \mathrm{C} / \mathrm{T}$ gene polymorphisms and CHB patients from Tehran, Iran. They observed no statically significant differences in terms of genotype distribution and allele frequency for both polymorphisms between healthy controls and patients with CHB. In another study (hospital-based) on HCV patients,
Romani et $\mathrm{a}^{44}$ found no significant differences in terms of the allelic frequency distribution of SNPs at $-509 \mathrm{C} / \mathrm{T},+869 \mathrm{C} / \mathrm{T}$, or $+915 \mathrm{G} / \mathrm{C}$ between $\mathrm{HCV}$ patients and healthy controls. In contrast, the hospital-based study of Talaat et $\mathrm{al}^{4}$ on 65 Egyptian hepatitis B patients and 50 healthy controls indicated that the T29C CC genotype might act as a host genetic factor of HBV susceptibility in Egyptians.

In conclusion, our findings suggest that theTGF $\beta 1+869 \mathrm{C} / \mathrm{T}$ and $+11929 \mathrm{C} / \mathrm{T}$ polymorphisms are associated with a lower and higher risk of CHB infection, respectively, in a SouthEast Iranian population. Moreover, the TTT or CCC (+869/$509 /+11929)$ haplotype carriers were at a higher or reduced risk of CHB, respectively. The main limitation of this study were that serum TGF- $\beta 1$ levels were not measured was and data regarding population risk factors for $\mathrm{HBV}$ infection and identification of the actual population were missed. However, the advantage of our study was the large number of subjects and the fact that it was a population-based study. Further studies using larger sample size on different ethnicities are suggested to confirm out findings regarding the implication of theTGF $\beta 1$ variants in CHB infection risk.

\section{Acknowledgements}

The authors appreciate all individuals who willingly participated in the current study.

\section{Conflict of Interest}

The authors declare that there is no conflict of interest.

\section{Financial Support}

This study was funded by Zahedan University of Medical Sciences, Zahedan, Iran.

\section{REFERENCES}

1. Zhang TC, Pan FM, Zhang LZ, Gao YF, Zhang ZH, Gao J, et al. A meta-analysis of the relation of polymorphism at sites -1082 and -592 of the IL-10 gene promoter with susceptibility and clearance to persistent hepatitis B virus infection in the Chinese population. Infection 2011;39(1):21-7.

2. de Andrade Jr DR, de Andrade DR. The influence of the human genome on chronic viral hepatitis outcome. Rev Inst Med Trop Sao Paulo. 2004;46(3):119-26.

3. Karimi-Googheri M, Daneshvar H, Nosratabadi R, Zare-Bidaki M, Hassanshahi G, Ebrahim M, et al. Important roles played by TGFbeta in hepatitis B infection. J Med Virol. 2014;86(1):102-8.

4. Talaat RM, Dondeti MF, El-Shenawy SZ, Khamiss OA. Transforming growth factor- beta 1 gene polymorphism (T29C) in Egyptian patients with hepatitis b virus infection: a preliminary study. Hepat Res Treat. 2013;2013:ID 293274.

5. Hosseini Razavi A, Azimzadeh P, Mohebbi SR, Hosseini SM, Romani S, Khanyaghma M, et al. Lack of Association Between Transforming Growth Factor Beta $1-509 \mathrm{C} / \mathrm{T}$ and $+915 \mathrm{G} / \mathrm{C}$ Polymorphisms and Chronic Hepatitis B in Iranian Patients. Hepat Mon. 2014;14(4):e13100. 
6. Ma J, Liu YC, Fang Y, Cao Y, Liu ZL. TGF-betal polymorphism 509 $\mathrm{C}>\mathrm{T}$ is associated with an increased risk for hepatocellular carcinoma in HCV-infected patients. Genet Mol Res. 2015;14(2):4461-8.

7. Bravo MJ, Colmenero JD, Queipo-Ortuño MI, Alonso A, Caballero A. TGF-beta1 and IL-6 gene polymorphism in Spanish brucellosis patients. Cytokine. 2008;44(1):18-21.

8. Qi P, Chen YM, Wang H, Fang M, Ji Q, Zhao YP, et al. -509C $>$ T polymorphism in the TGF-betal gene promoter, impact on the hepatocellular carcinoma risk in Chinese patients with chronic hepatitis B virus infection. Cancer Immunol Immunother. 2009;58(9):1433-40.

9. Xie HY, Wang WL, Yao MY, Yu SF, Feng XN, Jin J, et al. Polymorphisms in cytokine genes and their association with acute rejection and recurrence of hepatitis B in Chinese liver transplant recipients. Arch Med Res. 2008;39(4):420-8.

10. Zhou J, Chen DQ, Poon VK, Zeng Y, Ng F, Lu L, et al. A regulatory polymorphism in interferon-gamma receptor 1 promoter is associated with the susceptibility to chronic hepatitis B virus infection. Immunogenetics. 2009;61(6):423-30.

11. Saxena R, Kaur J. Th1/Th2 cytokines and their genotypes as predictors of hepatitis B virus related hepatocellular carcinoma. World J Hepatol. 2015;7(11):1572-80.

12. Kim YJ, Lee HS, Im JP, Min BH, Kim HD, Jeong JB, et al. Association of transforming growth factor-betal gene polymorphisms with a hepatocellular carcinoma risk in patients with chronic hepatitis B virus infection. Exp Mol Med. 2003;35(3):196-202.

13. Koch W, Hoppmann P, Mueller JC, Schomig A, Kastrati A. Association of transforming growth factor-betal gene polymorphisms with myocardial infarction in patients with angiographically proven coronary heart disease. Arterioscler Thromb Vasc Biol. 2006;26(5):1114-9.

14. Syrris P, Carter ND, Metcalfe JC, Kemp PR, Grainger DJ, Kaski JC, et al. Transforming growth factor-betal gene polymorphisms and coronary artery disease. Clin Sci (Lond) 1998;95(6):659-67.

15. Amirzargar AA, Rezaei N, Jabbari H, Danesh AA, Khosravi F, Hajabdolbaghi M, et al. Cytokine single nucleotide polymorphisms in Iranian patients with pulmonary tuberculosis. Eur Cytokine Netw. 2006;17(2):84-9.

16. Budak F, Goral G, Heper Y, Yilmaz E, Aymak F, Basturk B, et al. IL-10 and IL-6 gene polymorphisms as potential host susceptibility factors in Brucellosis. Cytokine. 2007;389(1):32-6.

17. Gewaltig J, Mangasser-Stephan K, Gartung C, Biesterfeld S, Gressner AM. Association of polymorphisms of the transforming growth factor-betal gene with the rate of progression of HCVinduced liver fibrosis. Clin Chim Acta. 2002;316(1-2):83-94.

18. Rafiei A, Hajilooi M, Shakib RJ, Alavi SA. Transforming growth factor-betal polymorphisms in patients with brucellosis: an association between codon 10 and 25 polymorphisms and brucellosis. Clin Microbiol Infect 2007;13(1):97-100.

19. Karaoglan I, Pehlivan S, Namiduru M, Pehlivan M, Kilincarslan C, Balkan Y, et al. TNF-alpha, TGF-beta, IL-10, IL-6 and IFN-gamma gene polymorphisms as risk factors for brucellosis. New Microbiol 2009;32(2):173-8.

20. Lok AS, McMahon BJ. Chronic hepatitis B. Hepatology. 2007;45(2):507-39.

21. Sepanjnia A, Eskandari-Nasab E, Moghadampour M, Tahmasebi A, Dahmardeh F. TGFbetal genetic variants are associated with an increased risk of acute brucellosis. Infect Dis (Lond). 2015;47(7):458-64.

22. Eskandari-Nasab E, Moghadampour M, Sepanj-Nia A. TNFalpha $-238,-308,-863$ polymorphisms, and brucellosis infection. Hum Immunol. 2016;77(1):121-125.
23. Heidari Z, Mahmoudzadeh-Sagheb H, Rigi-Ladiz MA, Taheri M, Moazenni-Roodi A, Hashemi M. Association of TGF-betal $-509 \mathrm{C} / \mathrm{T}, 29 \mathrm{C} / \mathrm{T}$ and $788 \mathrm{C} / \mathrm{T}$ gene polymorphisms with chronic periodontitis: a case-control study. Gene 2013;518(2):330-4.

24. Solé X, Guinó E, Valls J, Iniesta R, Moreno V. SNPStats: a web tool for the analysis of association studies. Bioinformatics. 2006;22(15):1928-9.

25. Lewontin RC. The detection of linkage disequilibrium in molecular sequence data. Genetics. 1995;140(1):377-88.

26. Wang KX, Peng JL, Wang XF, Tian Y, Wang J, Li CP. Detection of $\mathrm{T}$ lymphocyte subsets and mIL-2R on surface of PBMC in patients with hepatitis B. World J Gastroenterol. 2003;9(9):2017-20.

27. Lohr HF, Gerken G, Schlicht HJ, Meryer zum Buschenfelde $\mathrm{KH}$, Fleischer B. Low frequency of cytotoxic liver-infiltrating $\mathrm{T}$ lymphocytes specific for endogenous processed surface and core proteins in chronic hepatitis B. J Infect Dis. 1993;168(5):1133-9.

28. Huggins JT, Sahn SA. Causes and management of pleural fibrosis. Respirology. 2004;9(4):441-7.

29. Basturk B, Karasu Z, Kilic M, Ulukaya S, Boyacioglu S, Oral B. Association of TNF-alpha -308 polymorphism with the outcome of hepatitis B virus infection in Turkey. Infect Genet Evol. 2008;8(1):20-5

30. Almeida NP, Santana GO, Almeida TC, Bendicho MT, Lemaire DC, Cardeal M, et al. Polymorphisms of the cytokine genes TGFB1 and IL10 in a mixed-race population with Crohn's disease. BMC Res Notes. 2013;6:387.

31. Li H, Romieu I, Wu H, Sienra-Monge JJ, Ramirez-Aguilar M, del Rio-Navarro BE, et al. Genetic polymorphisms in transforming growth factor beta-1 (TGFB1) and childhood asthma and atopy. Hum Genet. 2007;121(5):529-38.

32. Schrijver HM, Crusius JB, Garcia-Gonzalez MA, Polman $\mathrm{CH}$, Pena AS, Barkhof F, et al. Gender-related association between the TGFB1+869 polymorphism and multiple sclerosis. J Interferon Cytokine Res. 2004;24(9):536-42.

33. Sivangala R, Ponnana M, Thada S, Joshi L, Ansari S, Hussain $\mathrm{H}$, et al. Association of cytokine gene polymorphisms in patients with tuberculosis and their household contacts. Scand J Immunol. 2014;79(3):197-205.

34. Ribeiro CS, Visentainer JE, Moliterno RA. Association of cytokine genetic polymorphism with hepatitis B infection evolution in adult patients. Mem Inst Oswaldo Cruz. 2007;102(4):435-40.

35. Mak JC, Leung HC, Sham AS, Mok TY, Poon YN, Ling SO, et al. Genetic polymorphisms and plasma levels of transforming growth factor-beta(1) in Chinese patients with tuberculosis in Hong Kong. Cytokine. 2007;40(3):177-82.

36. Pooja S, Francis A, Rajender S, Tamang R, Rajkumar R, Saini KS, et al. Strong impact of TGF-betal gene polymorphisms on breast cancer risk in Indian women: a case-control and population-based study. PLoS One. 2013;8(10):e75979.

37. Yu SK, Kwon OS, Jung HS, Bae KS, Kwon KA, Kim YK, et al. Influence of transforming growth factor-betal gene polymorphism at codon 10 on the development of cirrhosis in chronic hepatitis B virus carriers. J Korean Med Sci. 2010;25(10):564-9.

38. Frydecka D, Misiak B, Beszlej JA, Karabon L, Pawlak-Adamska E, Tomkiewicz A, et al. Genetic variants in transforming growth factor-beta gene (TGFB1) affect susceptibility to schizophrenia. Mol Biol Rep. 2013;40(10):5607-14.

39. Dunning AM, Ellis PD, McBride S, Kirschenlohr HL, Healey CS, Kemp PR, et al. A transforming growth factorbetal signal peptide variant increases secretion in vitro and is associated with increased incidence of invasive breast cancer. Cancer Res. 2003;63(10):2610-5. 
40. Besnard AG, Sabat R, Dumoutier L, Renauld JC, Willart M, Lambrecht B, et al. Dual Role of IL-22 in allergic airway inflammation and its cross-talk with IL-17A. Am J Respir Crit Care Med. 2011;183(9):1153-63.

41. Eskandari-Nasab E, Sepanjnia A, Moghadampour M, HadadiFishani M, Rezaeifar A, Asadi-Saghandi A, et al. Circulating levels of interleukin (IL)-12 and IL-13 in Helicobacter pylori-infected patients, and their associations with bacterial CagA and VacA virulence factors. Scand J Infect Dis. 2013;45(5):342-9.

42. Eskandari-Nasab E, Moghadampour M, Asadi-Saghandi A, Kharazi-Nejad E, Rezaeifar A, Pourmasoumi H. Levels of
interleukin-(IL)-12p40 are markedly increased in Brucellosis among patients with specific IL-12B genotypes. Scand J Immunol. 2013;78(1):85-91.

43. de la Fuente RA, Gutiérrez ML, Garcia-Samaniego J, FernándezRodriguez C, Lledó JL, Castellano G. Pathogenesis of occult chronic hepatitis B virus infection. World J Gastroenterol. 2011;17(12):1543-8.

44. Romani S, Azimzadeh P, Mohebbi SR, Kazemian S, Almasi S, Naghoosi H, et al. Investigation of Transforming Growth Factorbeta1 Gene Polymorphisms Among Iranian Patients With Chronic Hepatitis C. Hepat Mon. 2011;11(11):901-6. 